\title{
Współpraca instytucji finansowych z sektorem FinTech
}

\author{
MirostaWa Mioducka ${ }^{1}$, Teresa ŁUCZKA $^{2}$ \\ ${ }^{1} \mathrm{mgr}$, Politechnika Poznańska \\ e-mail:miroslawa.mioducka@op.pl \\ 2 prof. dr hab., Politechnika Poznańska \\ e-mail: teresa.luczka@put.poznan.pl
}

SŁowa kLUCzowe PSD2, FinTech, sektor finansowy, bankowość

Abstrakt Cel - przedstawiono możliwości współpracy firm typu FinTech z przedsiębiorstwami z sektora finansowego.

Metodyka badania - przegląd i analiza wyników badań wtórnych

Wynik - minimalizacja kosztów w sektorze bankowym poprzez zmianę sposobu obsługi klientów (przeniesienie do kanałów zdalnych) oraz nawiązanie współpracy z przedsiębiorstwami z sektora FinTech

Wartość - Perspektywy rozwoju współpracy instytucji finansowych z sektorem przedsiębiorstw FinTech

\section{Cooperation of financial institutions with the FinTech sector}

KEYWORDS PSD2, FinTech, financial sector, bankig

ABSTRACT Purpose - the article will be possibilities of FinTech companies cooperation with companies from the financial sector.

Methodology - review and analysis of secondary research result

Findings - minimization of costs in the banking sector by changing the way customer service (transfer to remote channels) and to establish cooperation with FinTech's.

Value - prospect for development of cooperation between financial institutions and FinTech's.

\section{Wprowadzenie}

Ostatnie kilkadziesiąt lat w sektorze finansowym, to lata szybkich z zmian technologicznych, implementacji nowych usług, związanych głównie ze zmianami w strukturach IT. W porównaniu z małymi firmami z branży technologicznej, korporacje takie jak banki, nie nadążają na bieżąco z wprowadzaniem zmian w IT. W zależności od wielkości organizacji i stopnia zbiurokratyzowania, wprowadzenie nowych rozwiązań trwa od kilku tygodni do dwóch lat. Rozwiązanie, które 
w fazie pomysłu mogło uchodzić za nowoczesne i innowacyjne, w fazie implementacji może być już przestarzałe. W sytuacji gdy dla klienta coraz większą rolę odgrywa prosty i szybki dostęp do usług finansowych wielu korzysta z rozwiązań dostarczanych przez firmy technologiczne z sektora FinTech. Są to głównie start-upy (chociaż nie jest to reguła) wykorzystujące technologię przede wszystkim do generowania przychodów poprzez świadczenie usług finansowych klientom bezpośrednio lub poprzez partnerstwo z tradycyjną instytucją finansową (Wilson, 2017).

W artykule przedstawiono możliwości współpracy pomiędzy sektorem finansowym a przedsiębiorstwami z branży FinTech oraz informacje o zmianach prawnych, wprowadzonych przez dyrektywę Parlamentu Europejskiego i Rady w sprawie usług płatniczych w ramach rynku wewnętrznego (Payment Services Directive 2, czyli PSD2), które tę współpracę zacieśnią. Wnioski przedstawiono na podstawie przeglądu i analizy wyników badań wtórnych.

\section{Rozwój bankowości w Polsce po 1989 roku}

W 1989 roku utworzono dwustopniową strukturę bankowości. Z regionalnych placówek Narodowego Banku Polskiego utworzono dziewięć niezależnych, regionalnych banków komercyjnych (Raport NBP, 2001). Rozpoczął się nowy etap dla sektora bankowego w Polsce. Po latach gospodarki centralnie sterowej, odizolowania od nowych technologii, gdzie NBP nadzorował działalność pozostałych sześciu państwowych banków, należało się zmierzyć z nowymi realiami panującymi na wolnym rynku. Pierwszy bankomat w Polsce powstał w 1990 roku, natomiast pierwsza karta została wydana w 1991 roku przez Bank Polska Kasa Opieki SA (PKO SA), była to karta połączona $\mathrm{z}$ rachunkiem oszczędnościowym. W tym samym roku na rynku pojawiła się międzynarodowa karta płatnicza VISA, typu Business w ofercie Banku Inicjatyw Gospodarczych SA (Raport NBP, 2001). Nadal brakowało jednak odpowiedniego zaplecza technicznego, poza tym Polacy byli przyzwyczajeni do posługiwania się gotówką, więc po tylu latach noszenia banknotów w portfelu trudno było zmienić przyzwyczajenia i zamienić pieniądze na plastik. Gwałtowny rozwój płatności elektronicznych nastąpił w 1995 roku. Wtedy też pojawiła się pierwsza karta kredytowa oferowana przez Bank PKO SA. Nastąpił wtedy również wzrost świadomości Polaków, którzy mogli bez problemów wyjeżdżać za granicę na wakacje czy do pracy i zdobytą tam wiedzę o poziomie, sposobach i standardach obsługi chcieli zaimplementować na rynek polski.

Wejście na rynek banków z kapitałem zagranicznym pozwoliło na zapoznanie się z nowymi sposobami obsługi klienta i wdrożeniem ich w Polsce. Opóźnienie we wprowadzaniu nowych technologii miało też swój pozytywny aspekt, mianowicie, można było uczyć się na błędach poprzedników. Pozwoliło to na pewno na uniknięciu wielu błędów podczas tworzenia aplikacji, zmniejszyło koszty i skróciło czas powstawania, pozwoliło na wprowadzenie lepszych i pewniejszych zabezpieczeń już na początku funkcjonowania. Obecnie polska bankowość jest liderem zaawansowanej bankowości, co przekłada się również na szybką adaptację nowych technologii przez klientów. Przedstawiciele pokolenia Y, czyli osoby urodzone pomiędzy 1980 a 1995 rokiem chętnie korzystają z nowinek technologicznych proponowanych przez banki.

Jak wskazują dane na rysunku 1, coraz więcej transakcji przebiega bezgotówkowo, a Polska jest w tym zakresie zdecydowanie powyżej średniej unijnej. 
Rysunek 1. Rola płatności gotówkowych i bezgotówkowych w wybranych krajach Europy i w Polsce

\begin{tabular}{|c|c|c|c|c|}
\hline Rumunia & 17 & \multicolumn{3}{|c|}{83} \\
\hline Bułgaria & 18 & \multicolumn{3}{|c|}{82} \\
\hline Węgry & 27 & \multicolumn{3}{|c|}{73} \\
\hline Słowacja & 31 & \multicolumn{3}{|c|}{69} \\
\hline Polska & 33 & \multicolumn{3}{|c|}{67} \\
\hline Czechy & 35 & \multicolumn{3}{|c|}{65} \\
\hline Niemcy & 40 & & \multicolumn{2}{|l|}{60} \\
\hline Hiszpania & \multicolumn{2}{|c|}{52} & \multicolumn{2}{|c|}{48} \\
\hline Wielka Brytania & \multicolumn{3}{|c|}{75} & 25 \\
\hline Francja & \multicolumn{3}{|c|}{75} & 25 \\
\hline Szwecja & \multicolumn{3}{|c|}{77} & 23 \\
\hline
\end{tabular}

Płatności bezgotówkowe kartą w Polsce (\%)

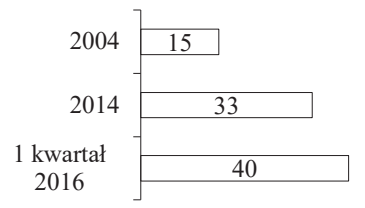

Źródło: http://www.pwc.pl/pl/pdf/sektor-finansowy-coraz-bardziej-fintech-raport-pwc.pdf.

Przykładem szybkiej implementacji nowych technologii jest system płatności zbliżeniowych. Polska jest jednym z 10 krajów przodujących w Europie w tej technologii, zaraz po Wielkiej Brytanii i Szwecji, ale Polacy wykonują ponad trzykrotnie więcej płatności bezstykowych w przeliczeniu na liczbę wydanych takich kart niż Anglicy. W 2015 roku w Polsce aż 55\% transakcji było przeprowadzanych kartami zbliżeniowymi. Kolejnym przykładem adaptacji nowych rozwiązań technologicznych jest bankowość mobilna - 61\% posiadaczy telefonu komórkowego korzysta z bankowości mobilnej (średnia w UE wynosi 40\%)ํ.

Wprowadzony w lutym 2015 roku przez Polski Standard Płatności Sp. z o.o. system płatności mobilnych BLIK umożliwia dokonywanie płatności z wykorzystaniem urządzeń przenośnych. Półtora roku po wprowadzeniu, BLIK obejmuje swoim zasięgiem:

- 7 banków (Alior Bank SA, Bank Millennium SA, Bank Zachodni WBK SA, ING Bank Śląski SA, mBank SA, PKO BP SA, Getin Noble Bank SA),

- 2 mln użytkowników (liczba zarejestrowanych aplikacji mobilnych BLIK),

- 157276 punktów handlowo-usługowych,

- 152043 terminali płatniczych,

- 36182 sklepów internetowych,

- 14273 bankomatów².

Przedstawione dane w tabeli 1 wskazują, że wzrost płatności ogółem w systemie BLIK w pierwszym półroczu 2016 roku wyniósł 61\% w porównaniu z drugim półroczem 2015 roku, natomiast dzienna liczba zrealizowanych zleceń w systemach płatności (tab. 2) w analogicznym okresie jest wyższa o $88 \%$ w porównaniu z pozostałymi systemami płatności, co jest zjawiskiem potwierdzającym duże możliwości adaptacyjne nowych technologii oraz sprzyjające rozwojowi obrotu bezgotówkowego.

\footnotetext{
${ }^{1}$ http://www.pwc.pl/pl/pdf/sektor-finansowy-coraz-bardziej-fintech-raport-pwc.pdf.

${ }^{2}$ http://www.nbp.pl/systemplatniczy/ocena/ocena2016_1.pdf.
} 
Biorąc pod uwagę duże zainteresowanie rozwojem technologii oraz szybki poziom jej absorpcji w bankowości, jedną z najszybciej rozwijających się branż technologicznych na świecie jest FinTech, czyli firmy dostarczające rozwiązania technologiczne wspierające usługi finansowe. Są to przedsiębiorstwa konkurujące z tradycyjnymi bankami, oferujące usługi zorientowane na klienta (Diekhoner, 2017). Firmy te, w przeciwieństwie do banków, potrafią szybko reagować na zmiany otoczenia, nie agregują wielu serwisów, ale skupiają się na dostarczeniu jednego, wybranego rozwiązania ${ }^{3}$. Prognozowany jest globalny wzrost inwestycji w firmy należące do tego sektora nawet o 55\% rocznie do 2020 roku, gdy jego poziom może przekroczyć 130 mld euro. Analitycy firmy Delloite podkreślają się, że w 106 mln Europie Środkowej i Wschodniej 75\% osób ma dostęp do internetu, a 55\% do smartfona, natomiast aktywa samych instytucji finansowych wynoszą ponad 2 bln euro w bankowości i 45 mld euro w ubezpieczeniach. To wszystko świadczy o dużym potencjale rozwoju ${ }^{4}$.

Tabela 1. Wartość i liczba zleceń w systemie BLIK w II półroczu 2015 roku oraz I półroczu 2016 roku

\begin{tabular}{|l|c|c|c|}
\hline \multicolumn{1}{|c|}{ System BLIK } & II półrocze 2015 r. & I półrocze 2016 r. & \multirow{2}{*}{ Zmiana (\%) } \\
\hline Liczba dni roboczych & 184 dni & 182 dni & \multirow{2}{*}{+61} \\
\hline \multicolumn{3}{|c|}{ Wartość płatności (mln zł) } \\
\hline Ogółem & 272,2 & 437,5 & +61 \\
\hline Średnia miesięczna & 45,4 & 72,9 & +63 \\
\hline Średnia dzienna & 1,479 & 2,404 & +86 \\
\hline \multicolumn{3}{|c|}{ Liczba płatności } \\
\hline Ogółem (mln) & 1,002 & 1,863 & +86 \\
\hline Średnia miesięczna & 167140 & 310570 & +88 \\
\hline Średnia dzienna & 5450 & 10239 & -14 \\
\hline Średnia kwota transakcji (zł) & 271 & 235 & \\
\hline
\end{tabular}

Źródło: http://www.nbp.pl/systemplatniczy/ocena/ocena2016_1.pdf.

Tabela 2. Porównanie średniej dziennej liczby zrealizowanych zleceń w systemach płatności w drugim półroczu 2015 roku i w pierwszym półroczu 2016 roku

\begin{tabular}{|l|c|c|c|}
\hline \multicolumn{1}{|c|}{ Systemy płatności } & II połowa 2015 r. & I połowa 2016 r. & Zmiana (\%) \\
\hline Elixir (mln) & 6,48 & 6,81 & $+5,51$ \\
\hline Euro Elixir & 75249 & 79821 & $+6,10$ \\
\hline SORBNET2 & 14653 & 15295 & $+4,40$ \\
\hline BlueCash & 7562 & 9644 & $+28,00$ \\
\hline BLIK & 5450 & 10239 & $-0,70$ \\
\hline TARGET2-NBP & 5135 & 5097 & $+37,00$ \\
\hline Express Elixir & 4385 & 6001 & \\
\hline
\end{tabular}

Źródło: http://www.nbp.pl/systemplatniczy/ocena/ocena2016_1.pdf.

${ }^{3}$ http://www.nbp.pl/systemplatniczy/ocena/ocena2016_1.pdf.

${ }^{4}$ https://www2.deloitte.com/pl/pl/pages/press-releases/articles/rynek-fintech-w-europie-srodkowo-wschodniej.html 
Czy to oznacza, że wypełnią się słowa Billa Gatese’a, który wiele lat temu zapowiedział, że bankowość będzie potrzebna, ale banki już niekoniecznie. Konieczność inwestowania w nowe technologie i poszukiwania ich na rynku, skieruje sektor w stronę mariażu z firmami typu FinTech. Banki w poszukiwaniu rozwiązań mobilnych, z zakresu big data czy CRM, będą szukały dostawcy, który zapewni im odpowiednie oprogramowanie o wysokim stopniu bezpieczeństwa i spełniającym wymagania klientów, które są coraz wyższe. Jest to pole do zagospodarowania zarówno dla dużych istniejących już rynkowych graczy, jak i dla innowacyjnych start-upów. W najbliższym czasie te dwa sektory mają szansę na większe zacieśnienie współpracy.

\section{Skutki wprowadzenia Payment Services Directive 2 (PSD2)}

Wprowadzenie dyrektywy Parlamentu Europejskiego i Rady (z 25.11.2015 r.) w sprawie usług płatniczych w ramach rynku wewnętrznego (Payment Services Directive 2, czyli PSD2), wprowadza zasadnicze zmiany dla rynku finansowego, na którym znaczenie mają głównie duzi gracze z sektora bankowego, jak również umozliwia wejście na nowe rynki dla firm, które do tej pory nie zajmowały się finansami. Wprowadzenie PSD2 jest rezultatem wzrostu znaczenia e-gospodarki na rynku, wprowadzenia usług świadczonych drogą elektroniczną, np. usług płatniczych, które nie były do tej pory regulowane. Ustawodawcy zależy na zwiększeniu bezpieczeństwa transakcji, zabezpieczeniu danych konsumentów, ale głównie uregulowaniu nowego, internetowego i mobilnego rynku technologii płatniczych. Główne zmiany, które wprowadza PSD2 obejmują:

1. Wprowadzenie nowej kategorii usługodawców na rynku usług płatniczych - dostawcy usług płatniczych, będącego osobą trzecią (TPP, czyli Third Party Provider); TPP można podzielić na dwa rodzaje:

a) Account Information Services (AIS), czyli dostęp online do informacji o stanie rachunków bankowych (w przypadku posiadania kont w różnych bankach), co ułatwia klientowi kontrolowanie środków finansowych w wielu instytucjach finansowych jednocześnie;

b) Payment Initiation Services (PIS), czyli pośrednictwo w płatnościach na życzenie klienta; podczas transakcji klient wybiera TPP i wskazuje instytucję, w której ma rachunek bankowy, TPP kontaktuje się ze wskazaną instytucją, aby zainicjować transakcję, następnie klient udostępnia login i hasło do swojego konta internetowego a TPP finalizuje zlecenie i potwierdza nadawcy i odbiorcy wykonanie przelewu.

2. Wprowadzenie tzw. silnego uwierzytelnienia polega na zastosowaniu przynajmniej dwóch elementów z takich kategorii, jak wiedza, którą tylko użytkownik ma, czyli np. znajomość hasła i PIN-u, kryterium posiadania (na przykład karty lub urządzenia generującego kod uwierzytelniający) lub też cech wrodzonych, czyli biometrycznych.

3. Zniesione opłaty za płatność konsumencką kartą płatniczą.

4. Podniesienie progu odpowiedzialności klienta za straty spowodowane nieautoryzowanymi płatnościami z 50 euro do 150 euro $^{5}$.

\footnotetext{
${ }^{5}$ http://eur-lex.europa.eu/legal-content/PL/TXT/PDF/?uri=CELEX:32015L2366\&from=DE.
} 
Pośrednik w realizacji przelewów nie jest nowością na rynku usług finansowych. Na takiej samej zasadzie działają obecnie szybkie przelewy elektroniczne, tzw. pay-by-link, wykonywane po przekierowaniu z e-sklepu do serwisu banku. Jak wynika z badania ICAN Research na zlecenie Płatności Online BM, przeprowadzonego w 2015 roku, aż 71\% kupujących w internecie korzysta z takiego rozwiązania ${ }^{6}$. Co w takim razie zmienia PSD2? Nowe rozwiązanie będzie polega na tym, że klient podczas realizacji płatności będzie podawał TPP swoje dane do logowania, co obecnie jest sprzeczne z regulaminami bankowymi oraz nie jest zgodne z rekomendacjami Komisji Nadzoru Finansowego. Banki oraz cały sektor będą musiały przystosować zapisy w swoich regulaminach, aby umożliwić klientom korzystanie z usług TPP, ale również same będą mogły pełnić taką funkcję, co oznacza dodatkową formę potencjalnego dochodu. Dostosowanie infrastruktury bankowej do zapisów dyrektywy wiąże się również z dużymi kosztami, ponieważ banki muszą wpleść w swoją strukturę interfejs, który umożliwi TPP korzystanie z bankowej bazy klientów. Najbardziej negatywnym skutkiem dyrektywy dla banków jest utrata wyłączności na zgromadzone przez lata dane klientów, które stanowią know-how banków. W nowej rzeczywistości wszystkie firmy, które świadczą usługi związane z udzielaniem kredytów będą mogły mieć wgląd do historii konta klienta, aby móc ocenić jego zdolność kredytową i oszacować potencjalne ryzyko z jakim wiąże się udzieleniem kredytu danemu podmiotowi. Cały sektor będzie musiał rozwiązać problem bezpiecznego przekazywania informacji, zapewnienia właściwego poziomu ochrony danych oraz uregulowania zasad pomiędzy TPP a bankami.

TPP mogą zostać zarówno banki, jak i firmy z sektora FinTech. Kilka najbliższych miesięcy instytucje finansowe poświecą na przygotowanie infrastruktury i podjęcia decyzji o sposobie współpracy z firmami technologicznymi, aby w jak najlepszy sposób wykorzystać możliwość zdobycia klientów.

\section{Wpływ Payment Services Directive 2 (PSD2) na sektor bankowy w Polsce oraz sektor FinTech}

Zgodnie z raportem Pricewaterhouse Coopers „Sektor finansowy coraz bliżej FinTech” istnieją trzy możliwe scenariusze po wejściu w życie restrykcji PSD2:

- tradycyjne instytucje finansowe stracą 20\% udziałów w rynku na rzecz FinTech,

- wiele banków zniknie z rynku, pozostałe znacznie zmniejszą swoją rolę i staną się instytucjami oferującymi podstawowe usługi finansowe,

- nastąpi symbioza i wielopłaszczyznowa współpraca tradycyjnych instytucji finansowych z firmami FinTech.

Trzeci scenariusz jest najbardziej realny z kilku powodów. Po pierwsze, polski sektor bankowy jest bardzo wysoko rozwinięty pod względem technologicznym. Związane jest to z opóźnieniem w rozpoczęciu działalności w gospodarce wolnorynkowej, dzięki czemu banki nie musiały modernizować starej infrastruktury technologicznej, tylko skorzystały już z istniejących, nowoczesnych rozwiązań technologicznych. Jest to branża na tyle rozwinięta technologicznie i dojrzała, że zamiast obawiać się konkurencji, zaprosi ją do współpracy.

\footnotetext{
${ }^{6} \mathrm{http} / / /$ www.bankier.pl/wiadomosc/PSD2-rewolucja-czy-ewolucja-w-platnosciach-7331323.html

${ }^{7}$ http://www.pwc.pl/pl/publikacje/2016/sektor-finansowy-coraz-bardziej-fintech-raport-pwc-polska.html
} 
Przykładem już nawiązanej współpracy są hackatony, zorganizowane przez Bank Zachodni WBK SA. Jedno z nich dotyczyło stworzenia aplikacji mobilnej z użyciem technologii Beacon. To małe nadajniki sygnału radiowego mogące komunikować się ze smartfonami użytkowników, działające już w muzeach, centrach handlowych ${ }^{8}$, a teraz sektor bankowy chce je wykorzystać np. w oddziałach. Gdy klient danego banku ma zainstalowaną odpowiednią aplikację i zbliża się do miejsca, w którym umieszczony jest Beacon, ten wysyła na telefon informacje handlowe lub zapraszające do wizyty w oddziale, a po wejściu do placówki, na komputerze pracownika wyświetlają się dane klienta.

Po drugie - nowej, małej firmie - nawet jeśli działa w sektorze FinTech, trudno jest zaistnieć na rynku - wsparcie dużych instytucji, takich jak banki, może pomóc w zdobyciu nowych klientów. Banki mogą wesprzeć ją nie tylko finansowo, ale również poinformować w mediach, że przy projekcie współpracowała z określonym start-upem. Przykładem może być Akademia Leona Koźmińskiego, która przy wsparciu między innymi Banku Zachodniego WBK SA, uruchomiła akcelerator dla przedsiębiorców, będących studentami lub absolwentami uczelni. Program ten zakłada, że firmy, które zostaną objęte patronatem, będą swoimi zasobami wspierały rozwój projektów prowadzonych przez partnerów biznesowych ${ }^{9}$.

Po trzecie, instytucje finansowe potrzebują wsparcia firm zewnętrznych w zakresie nowoczesnych rozwiązań z zakresu big data, CRM czy nowych form marketingu. Jednym z największych know-how banków jest dostęp do historii transakcji na kontach klientów. Odpowiednia reakcja na konkretne transakcje pozwala zapobiec odejściu klienta lub może skutkować odpowiednią kampanią sprzedażową. Aby móc w ten sposób zarządzać portfelem klienta, należy stworzyć odpowiednie algorytmy, dzięki którym możliwe będzie przeanalizowanie obrotów na kontach klientach i z dużym prawdopodobieństwem określić, jaki może być kolejny ruch klienta, co pozwoli zareagować w odpowiedni sposób. Nie wszystkie banki mają odpowiednie możliwości techniczne na stworzenie takich rozwiązań, dlatego będą szukać ich na rynku .

Po czwarte, bankom bardzo zależy na ograniczeniu ryzyka a tym samym na ograniczeniu kosztów. Kredyt jest jedną z form finansowania działalności gospodarczej, ale nie każde przedsiębiorstwo, szczególnie gdy dopiero rozpoczyna swoją działalność, może liczyć na takie finansowanie. Banki odrzucają wnioski kredytowe lub poszukują dodatkowych form zabezpieczenia. W odniesieniu do podmiotów gospodarczych, wiarygodność kredytową mają te firmy, których stan majątkowy oraz poziom efektywności finansowej prowadzonej działalności gospodarczej stwarzają pełne zabezpieczenie wykonania zobowiązań nie tylko wobec banku, ale wobec wszystkich wierzycieli ${ }^{10}$. Na rynku istnieją firmy, które mają większą skłonność do podejmowania ryzyka niż instytucje finansowe. Na tym polu można znaleźć możliwość współpracy z firmami, które:

- banki mogą polecać jako alternatywnego kredytodawcę, na podstawie podpisanej umowy o współpracy,

\footnotetext{
${ }^{8} \mathrm{http}: / / w w w . n e w s w e e k . p l / s t y l-z y c i a /$ beacon-co-to-takiego-i-do-czego-sie-go-uzywa,artykuly,364514,1.html.

${ }^{9}$ http://naukawpolsce.pap.pl/aktualnosci/news,407632, akademia-leona-kozminskiego-uruchomila-akcelerator-dlaprzedsiebiorcow.html.

${ }^{10}$ http://www.ekonomik.rzeszow.pl/attachments/article/643/SKRYPT.pdf s.30.
} 
- udzielą dodatkowego zabezpieczenia, które będzie wystarczające dla banku, aby udzielić kredytu.

Współpraca banków z sektorem FinTech może przynieść bankom znaczne obniżenie kosztów, co w bieżącej sytuacji rynkowej (niskie stopy procentowe, podatek bankowy, ryzyko wprowadzenia ustawy frankowej, niskie marże) jest dla sektora bankowego niezwykle istotne. Rozwój IT będzie skutkował niższymi kosztami działalności, związanymi głównie z obniżeniem kosztów pracowniczych. Mniejsza liczba oddziałów i pracowników w centrali oraz przeniesienie obsługi do zdalnych kanałów kontaktu, to wynik programów digitalizacji polskich banków. Wszystkie zmiany wiążą się z rozwojem nowych technologii, którą banki adaptują z rynku. Na rysunku 2 przedstawiono prognozowane dane o strukturze sektora finansowego, która ulegnie największym zmianom wskutek działalności branży FinTech. Największe zmiany czekają bankowość indywidualną oraz przekazy pieniężne, co związane jest z najliczniejszą grupą odbiorców oraz najbardziej zaawansowanymi technologiami, które są wykorzystywane w tych częściach sektora usług finansowych.

Rysunek 2. Segmenty sektora usług finansowych, które ulegną największym przemianom wskutek działalności FinTechów w ciągu pięciu najbliższych lat

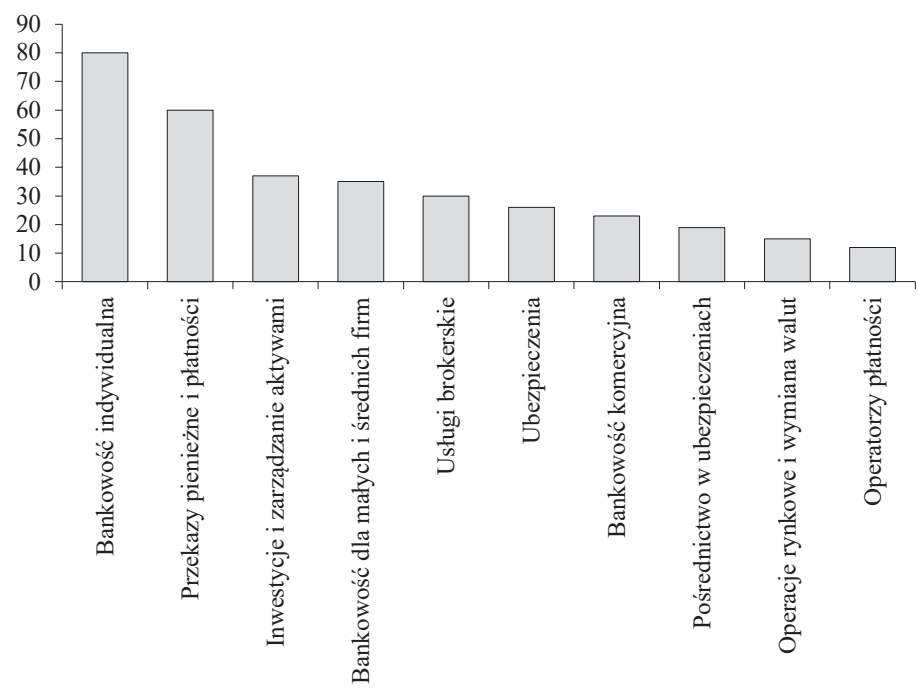

Źródło: http://www.pwc.pl/pl/pdf/sektor-finansowy-coraz-bardziej-fintech-raport-pwc.pdf.

Dane na rysunku 2 wskazują, że bankowość małych i średnich firm jest jednym z tych sektorów, które zmiany dotkną najbardziej. Jakie zmiany mogą czekać przedsiębiorców? mBank już umożliwił swoim firmowym klientom korzystanie z księgowości online ${ }^{11}$. Coraz więcej banków oferuje złożenie wniosku o kredyt w wersji elektronicznej, a po integracji systemów bankowych z Centralną Ewidencją i Informacją o Działalności Gospodarczej, zaraz po otwarciu

\footnotetext{
11 https://www.mbank.pl/firmy/ksiegowosc/wiecej.
} 
firmy, w systemach bankowych tworzy się folder potencjalnego klienta. Informacja ta następnie przekazywana jest do oddziału, który zlokalizowany jest najbliżej miejsca działalności firmy i doradca firmowy ma za zadanie skontaktować się z przedsiębiorcą w celu przedstawienia oferty. Banki mogą również tworzyć rachunki predefiniowane (np. mBank), które automatycznie podstawiają się podczas otwierania działalności gospodarczej w CEiIDG. W tej sytuacji nie ma już potrzeby wykonywania kolejnej czynności, jaką jest otwierania konta firmowego.

Po wejściu w życie dyrektywy PSD2 na rynku finansowym pojawią się nowi gracze, którzy, podobnie jak firmy Uber na rynku taksówkarskim czy Airbnb w branży hotelowej, będą tylko pośrednikami. Firmy te nie tworzą żadnych produktów, ale dzięki nim konsumenci uzyskali dostęp do tańszych usług. Takie zjawisko zyskało miano „uberyzacji”, a jednym z istniejących już rozwiązań na amerykańskim rynku finansowym, jest aplikacja firmy MoolahMe, która pozwala na podstawie geolokalizacji, na kojarzenie osób potrzebujących gotówki z tymi, które mają jej ${ }^{12}$.

Dane zaprezentowane na rysunku 3 pokazują jak w stosunkowo krótkim okresie wzrośnie znaczenie ekonomii dzielenia. Wzrost z 15 bln USD w 2015 roku do 335 bln w roku 2025 sugeruje, że powinno się zwrócić większą uwagę na ten sektor. Uwzględnienie na rysunku również mikropożyczek i finansowania społecznościowego uświadamia, że klienci po pożyczki coraz częściej będą się zwracać do pośredników, ponieważ taka forma jest zapewne tańsza, bardziej przystępna i wygodniejsza. Banki, aby nie stracić klientów i pozycji na rynku, będą musiały szukać nowych gałęzi rozwoju, gdzie będą zarówno instytucją zaufania publicznego (jak teraz), jak i stworzą spółki córki, świadczące usługi z sektora ekonomii dzielenia. Aby jednak w pełni wykorzystać możliwości, jakie daje rozwój technologii, potrzebny jest mariaż z firmami z sektora FinTech, które są w stanie dostarczyć niepowtarzalnych rozwiązań, dostosowanych do potrzeb klientów.

Rysunek 3. Prognozowany poziom przychodów sektorów ekonomii dzielenia się i tradycyjnych usług (bln USD)

2013

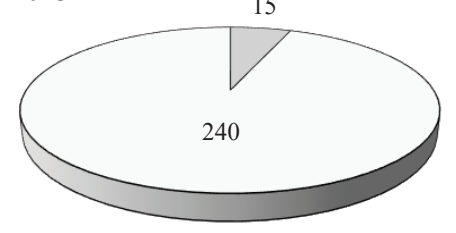

$\square$ Sektor ekonomii dzielenia
2025

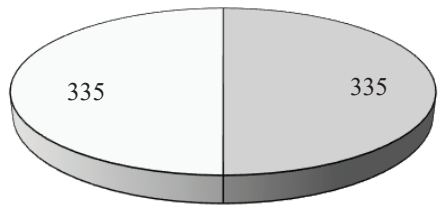

$\square$ Sektor tradycyjnych usług

Źródło: http://www.pi.gov.pl/PARP/chapter_86197.asp?soid=AD91F8EC92334FB1B2CF8C3A24F85777Jak.

Jak wynika z danych firmy Pricewaterhouse Coopers „How FinTech is shaping financial sevices" 13 , 25\% firm z sektora finansowego nie zamierza współpracować z firmami FinTech w ogóle. Wpływ na taką decyzję mają zapewne nakłady finansowe, które firmy będą musiały

\footnotetext{
12 http://www.pi.gov.pl/PARP/chapter_86197.asp?soid=AD91F8EC92334FB1B2CF8C3A24F85777.

${ }^{13}$ http://www.pwc.com/gx/en/advisory-services/FinTech/pwc-fintech-global-report.pdf.
} 
ponieść na nowe technologie. Takie same obawy pojawiają się w niemieckim sektorze finansowym $^{14}$, gdzie wyraża się obawę przeniesienia kosztów na klientów, szczególnie gdy TTP nie będzie musiał ponosić żadnych kosztów związanych z implementacją nowych rozwiązań, a jedynie korzystać z benefitów.

Mariaż finansów i nowych technologii wydaje się jednak nieunikniony ze względu na dynamiczny rozwój technologii i coraz większy jej udział w życiu klientów. W sytuacji braku współpracy instytucji finansowych z FinTech, może ziścić się natomiast scenariusz zakładający utratę ok. 20\% udziałów w rynku. Banki, z ekonomicznego i wizerunkowego punktu widzenia, nie mogą sobie pozwolić na utratę tak dużej liczby klientów, dlatego w najbliższych latach będziemy obserwować rozwój technologii z polskiej bankowości, przy współudziale branży FinTech.

\section{Podsumowanie}

W XXI wieku nie można wyobrazić sobie świata bez sektora finansowego, a tym bardziej bez bankowości online. W ciągu ostatnich 20-30 lat nastąpiła technologiczna rewolucja w sektorze finansowym na świecie i w Polsce. Nie stałoby się tak bez rozwoju nowoczesnych rozwiązań z zakresu IT oraz współpracy firm technologicznych z firmami z sektora finansowego. Te zmiany wynikają z konieczności zaspokajania coraz bardziej wysublimowanych potrzeb klienta, ale również z potrzeby minimalizowania kosztów, a najtańszym procesem obsługi klienta jest proces online, pozwalający wyeliminować czynnik ludzki. Na szybki rozwój technologii muszą reagować również regulatorzy, którzy dostosowują przepisy prawa do istniejących już na rynku rozwiązań i starają się mieć nad nimi pieczę i kontrolę.

\section{Literatura}

Ciesielski, M. (2016). „Bye, bye banks”. Banki nie będa nam potrzebne? Pobrano z: http://forsal.pl/artykuly/919157, wizja-billa-gates-a-dotyczaca-bankow.html (22.01.2017).

Diekhoner, P. (2017). The trust economy: building strong networks and realising exponential value in the digital age, Marshall Cavendish Business.

Naumoff, A. (2016). PSD2: German Regulator and Banks Are Not Happy With Each Other. Pobrano z: https:/cointele graph.com/news/psd2-german-regulator-and-banks-are-not-happy-with-each-other (12.02.2017).

Newsweek.pl (2015). Beacon: przewodnik po muzeum i kupon rabatowy w jednym. Czy przyjmie się w Polsce? Pobrano z: http://www.bankier.pl/wiadomosc/PSD2-rewolucja-czy-ewolucja-w-platnosciach-7331323.html (22.01.2017).

Naukawpolsce.pap.pl. (2015). Akademia Leona Koźmińskiego uruchomiła akcelerator dla przedsiębiorców. Pobrano z: http://naukawpolsce.pap.pl/aktualnosci/news,407632,akademia-leona-kozminskiego-uruchomila-akceleratordla-przedsiebiorcow.html (22.01.2017).

Nicoletti, B. (2017). The Future of FinTech: Integrating finance and technology in financial services

Dyrektywa Parlamentu Europejskiego i Rady (UE) 2015/2366 z 25.11.2015 r. w sprawie usług płatniczych w ramach rynku wewnętrznego, zmieniająca dyrektywy 2002/65/WE, 2009/110/WE, 2013/36/UE i rozporządzenie (UE) nr 1093/2010 oraz uchylająca dyrektywę 2007/64/WE.

mBank (2016). mKsięgowość. Pobrano z: https://www.mbank.pl/firmy/ksiegowosc/wiecej (22.01.2017).

Ptak, S. (2016). PSD2 - rewolucja czy ewolucja w płatnościach? Pobrano z: http://www.bankier.pl/wiadomosc/PSD2-rewolucja-czy-ewolucja-w-platnosciach-7331323.html (22.01.2017).

14 https://cointelegraph.com/news/psd2-german-regulator-and-banks-are-not-happy-with-each-other. 
Raport Deloitte (2016). FinTech w Europie Środkowo-Wschodniej. Pobrano z: https://www2.deloitte.com/pl/pl/pages/ press-releases/articles/rynek-fintech-w-europie-srodkowo-wschodniej.html (22.01.2017).

Raport NBP (2001). System Bankowy w Polsce w latach dziewięćdziesiatych. Pobrano z: http://www.nbp.pl/publikacje/ system_bankowy/system_bankowy.pdf (22.01.2017).

Raport NBP. (2015). Kredyt bankowy jako źródło finansowania działalności. Pobrano z: http://www.ekonomik.rze szow.pl/attachments/article/643/SKRYPT.pdf (22.01.2017).

Raport NBP (2016). Ocena funkcjonowania polskiego systemu płatniczego w I półroczu 2016 r. Pobrano z: http://www. nbp.pl/systemplatniczy/ocena/ocena2016_1.pdf (22.01.2017)

Raport PricewaterhouseCoopers (2016). Sektor finansowy coraz bardziej \#fintech. Pobrano z: http://www.pwc.pl/pl/ pdf/sektor-finansowy-coraz-bardziej-fintech-raport-pwc.pdf (22.01.2017)

PricewaterhouseCoopers global report (2016). Blurred lines: How FinTech is shaping financial services, Pobrano z: http://www.pwc.com/gx/en/industries/financial-services/fintech-survey/report.html (5.02.2017)

Remisiewicz, M. (2015). Uberyzacja - wielki przełom czy pułapka? Pobrano z: http://www.pi.gov.pl/PARP/chapter_ 86197.asp?soid=AD91F8EC92334FB1B2CF8C3A24F85777 (22.01.2017)

Wilson, J.D. (2017). Creating Strategic Value through financial technology. New Jersey: Wiley.

\section{Cytowanie}

Mioducka, M., Łuczka, T. (2016). Współpraca instytucji finansowych z sektorem FinTech. Współczesne Finanse. Teoria i Praktyka, 1 (1), 61-71. DOI: 10.18276/wf.2016.1-06. 